\title{
The Influence of Hairline Crack Eggs on Hatchery Parameters and Performance of Chicks
}

\author{
Adnan Jabbar ${ }^{1 *}$, Abdul Hameed ${ }^{2}$, Adnan Yousaf $^{3}$, Amjad Riaz $^{4}$ and Yasir Allah Ditta ${ }^{5}$ \\ ${ }^{1}$ Hatchery Manager Salman Poultry (Pvt.) Ltd Rawalpindi Pakistan \\ ${ }^{2}$ Deputy Director Livestock Punjab Department of livestock and Dairy Development KotAdu Punjab Pakistan \\ ${ }^{3}$ Assistant Farm Manager Salman Poultry (Pvt.) Ltd Nankana shb Sheikhupura Pakistan \\ ${ }^{4}$ Associate Professor Department of Animal Reproduction University of Veterinary and Animal Sciences Lahore \\ ${ }^{5}$ Assistant Professor Department of Animal Nutrition University of Veterinary and Animal Sciences Lahore \\ *Corresponding author’s Email: $\underline{\text { Sbhatcheryislamabad@gmail.com; ORCID: 0000-0003-1073-9565 }}$
}

\begin{abstract}
The purpose of study was to evaluate the influence of hairline crack eggs on hatchery parameters and later life of chicks. The study was conducted from October to December 2018 at Chakri hatchery Salman Poultry Pvt. Ltd Pakistan to evaluate the outcomes of hairline crack eggs. The shell of the eggs is essential in providing the shape of an egg and ensuring the safe packaging. The defects like breakage of this packaging increase the risk of microbial contamination. In this experiment, the crack eggs like hairline crack eggs were detected by Sanovo STAALKAT Alpha 125 Machine number JB 11786. The eggs were collected from eighteen different breeder farms. Each group contained $(n=50,000)$ eggs. The hairline crack eggs were compared with normal eggs for hatchability, candling, putrification/blasting and dead in shell. Significant difference was found for hatchability, candling, blasting/putrification and dead in the shell for normal and hairline crack eggs. The highest hatchability $(49.07 \pm 0.51)$ and lowest candling $(9.98 \pm 0.064)$ for hairline crack eggs were found for AP27 flock due to young age and good quality eggshell. The lowest hatchability was found for SP117 flock which was the oldest flock having thin egg shells. The blasting/putrification and dead in the shell were significantly higher for hairline crack eggs as compared to normal eggs of same flocks. The lowest blasting was found for AP27 flock. On a simple hatch debris analysis, the highest mortality, infertile, contaminated eggs were for first and third weeks. The higher mortality were found for hairline crack eggs as compared to the normal eggs for SSF5 flock. The water loss, chick yield and culling chicks percentage were also significantly better for normal eggs compared to hairline crack eggs. The hairline crack eggs of young flocks were better than old flocks due to a better quality of eggs shell. The chicks from normal eggs were also significantly better than chicks from hairline crack eggs in terms of mortality, feed intake, weight gain and FCR. The hairline crack eggs are the source of contamination. Present study recommended that hairline crack eggs do not use for incubation.
\end{abstract}

Key words: Candling, Dead in shell, Hairline crack, Hatchability, Water loss

\section{INTRODUCTION}

Fertility and hatchability are major determinants for profitability in a hatchery enterprise. A healthy chicken starts from a good quality intact breeder's egg. The egg is a multifunctional biomineral complex consists of highly structured calcium carbonate shell act as a barrier for growing embryo to prevent microbial invasion and provide mechanical strength (Wellman et al., 2008). The eggs should appear smooth and free of cracks by the naked eye. The damage of eggshell may occur at any level occasionally including transportation and while eggs settings. Some eggshell breakage may be complete crack, star crack, pimples, pinholes, sandpaper, leathery appearance and hairline cracks, account for approximately $0.5 \%$ to $6 \%$ of total eggs production (King'ori et al., 2012). Many scientists developed different techniques to identify the crack eggs (Wei et al., 2015) developed a magnetostrictive transducer technique to identify crack eggs. The swept vibration signals from 1 to $14 \mathrm{kHz}$ created in the computer by software. Then it was amplified by circuit board to drive the magnetostrictive transducer. The collision between the egg and magnetostrictive transducer generated sounds. The computer recorded the acoustic signals at $44 \mathrm{kHz}$ sampling rate through the microphone. The sampled acoustic signals contain rich information about the quality of the eggs. By analyzing the acoustic signals we can identify the egg is intact or not.

Another technique described by Xie and He (2016) which can be used for eggshellcolour and shell strength detection is hyperspectral imaging technique which can produce spectral information as well as spatial information for objectives at the same time. A spatial hyperspectral cube can be generated when one sample was scanned by the hyperspectral imaging camera. The hyperspectral cube (hyperspectral image) contains a series of images covering the whole wavelength, and each pixel for one image has both spectral and spatial information. Because of this feature, it can 
be used to detect external characteristics, such as fruit defect, colour and sugar beet disease and internal information, such as moisture content, other chemical indexes and eggshellcolour and shell strength.

The eggshell is protection for growing embryo to the external environment as well as microbial contamination. The breakage of eggshell provides an ideal rout entrance for penetrating microbes. Van den Brand et al. (2016) found that fertility and hatchability of clean eggs were higher than the floor or dirty eggs. Through the crack, shell microbes penetrate and cause embryonic mortality at any stage of incubation. Jabbar and Ditta (2017a) conducted an experiment to know the effect of floor eggs and found that floor eggs are a source of low hatchability, improper water loss, high candling and dead in shell. The floor eggs are a source of contamination. Salahi et al. (2011) also found that hairline cracks eggs become a source of low hatchability, high candling, high dead in shell and embryonic mortality as compared to star crack or intact shell eggs. Moreover, chick length, yolk-free body mass, breast and liver weight were significantly decreased than normal eggs. The contamination was higher for hairline crack eggs than that of star crack eggs. The aim of study was to evaluate the outcome from hairline crack eggs in term of hatchery parameters and its effects on later life of chicks.

\section{MATERIALS AND METHODS}

\section{Ethical approval}

This experiment was performed considering to all animal rights (Society for Protection and Care of Animals. University of veterinary and Animal Sciences, Pakistan)

\section{Site selection}

The experiment was performed at Salman Poultry (Pvt) Limited, Chakri Hatchery Rawalpindi which is situated 5 $\mathrm{km}$ from the Chakri interchange on the motorway (M2) Pakistan The hatchery is facilitated with latest Heating Ventilation and Air Conditioning (HVAC) automation, having ISO (International standard organization) 1900-2000 certified. This hatchery is one of the largest chicks producing hatchery of south Asia, which is producing 6.5-7 million high quality chicks through the single stage incubation system (Avida G4, Chick Master USA).

\section{Selection of eggs}

Each experimental group was consisting of n=50,000 eggs. SP 117-AI B, C, D, E, F (Salman Poultry Flock number 117 with artificial insemination (team B, C, D, E, F), Salman Poultry Flock number 5 (SSF5), Salman Poultry Flock number 6 (SSF6), Salman Poultry Flock number 1 with artificial insemination team C (SSF-R1-AI-C), Salman Poultry Flock number 2 with artificial insemination team A (SSF-R2-AI-A), Salman Poultry Flock number 2 with artificial insemination team B (SSF-R2-AI-B) and Salman Poultry Flock number 3 with artificial insemination team D (SSF-R3AI-D). Arslan Poultry flock number 27 (AP).

\section{Crack eggs detection}

The crack eggs detection was performed through STAALKAT Alpha 125 Machine number JB 11786. This machine has multiple functions including eggs grading on the basis of weight, crack eggs detection through sound, leaker and dirty eggs detection. The machine converts digital signals into multiple crack categories. The crack eggs detection was performed through this machine for each flock.

Table 1. Percentage of hairline crack eggs with respect to flock age

\begin{tabular}{lcc}
\hline Flocks & Hairline Crack (\%) & Flock Age (weeks) \\
\hline Salman Poultry Flock 117-2 & 0.5 & 60 \\
Salman Poultry Flock 117-1-AI-B & 1.18 & 60 \\
Salman Poultry Flock 117-1-AI-C & 1.17 & 60 \\
Salman Poultry Flock 117-1-AI-D & 1.18 & 60 \\
Salman Poultry Flock 117-1-AI-E & 1.17 & 60 \\
Salman Poultry Flock 117-1-AI-F & 1.17 & 60 \\
Salman Sadiq Flock 1-R1-AI-C & 0.8 & 46 \\
Salman Sadiq Flock1-R2-AI-A & 0.75 & 46 \\
Salman Sadiq Flock1-R2-AI-B & 0.79 & 46 \\
Salman Sadiq Flock1-R3-AI-D & 0.65 & 46 \\
Salman Sadiq Flock-5 & 0.41 & 41 \\
Salman Sadiq Flock-6 & 0.4 & 40 \\
Salman Sadiq Flock 2-Ross1 & 0.2 & 31 \\
Salman Sadiq Flock 2-Ross2 & 0.21 & 30 \\
Salman Sadiq Flock 8 & 0.21 & 30 \\
Salman Sadiq Flock 2-Ross3 & 0.20 & 29 \\
Arslan Poultry Flock 27-Ross2 & 0.20 & 29 \\
Arslan Poultry flock 27-Ross1 & 0.19 & 28 \\
\hline
\end{tabular}




\section{Weight of eggs}

Before setting the egg's weight of each individual group was calculated by setting eggs into one setter tray then applying the formula,

Egg weight: Full tray weight at Setting- Weight of empty tray

Total No of eggs in tray

\section{Eggs fumigation}

Before the weighing, the trial eggs were fumigated with $20 \mathrm{~g} \mathrm{KMnO}_{4}$ and $40 \mathrm{ml}$ formalin (40\%) and $40 \mathrm{ml}$ of water for $100 \mathrm{ft}^{3}$ areas for 15 minutes through automatic fumigation process provided by Chick Master.

\section{Incubation programme}

Standard incubation profiles recommended by chick master were selected on the basis of breeder's age. Pre-heating was performed for all experimental groups following automatically the incubation stage profile (Recommended by Chicks Master USA).

\section{Setter hall and hatcher hall}

Environmental conditions in setter hall were at $75^{\circ} \mathrm{F}$ temperatures and $40 \%$ relative humidity; whereas in the hatcher hall temperature was at $75^{\circ} \mathrm{F}$ and relative humidity had been increased up to $60 \%$. The positive pressure in setter and hatcher hall was 15 Pascal and 10 Pascal respectively, while negative pressure inside setter and hatcher plenum was 25 Pascal during the course study.

\section{Candling}

Fertility of eggs was performed through candling then shifted to hatchers for next $50 \mathrm{hrs}$. These entire incubation stage programs have been recommended by chick master USA.

\section{Egg's weight loss}

Before being transferred from setter to hatchers water loss e-g egg weight loss was measured for from each group individually after $456 \mathrm{hrs}$ of incubation in setters by the given formula:

Water Loss \%: Full tray weight at Setting- Full Tray Weight at Transfer $\times 100$

$$
\text { Full tray weight at Setting- Empty Tray Wight }
$$

\section{Chick yield}

After hatch pulls out immediately, the chick's weight was measured through electrical weight balance to know the chick yield using following formula:

Chick Yield \%: $\frac{\text { Weight of chick's } \times 100}{\text { Egg weight }}$

\section{Hatch window}

Hatch window was done between the first chicks to last chick hatch out (Noiva et al., 2014). The range of hatch window was measured through the graph produced by Maestro software (Chick Master USA). The increase hatching process inside hatcher becomes a source of increase humidity which can be easily detected.

\section{Chick grading}

Grading of chicks was performed on the conveyor and automatic grading table while chicks counting and packing was performed through chick counter (KUHL-USA). Only stranded (shining eyes, soft legs and nose, healed naval and healthy chicks) were shifted to chick's box after counting, while underweight, weak, and unhealed naval chicks were removed as an international standard as described by Yousaf et al. (2017).

\section{Hatch out analysis}

Hatch out analysis was performed to investigate the reason of embryo's mortality inside the eggs as described by Jabbar and Ditta (2017a, b and c).

\section{Poultry house}

The chicks from normal $(n=30000)$ and hairline crack eggs $(n=30000)$ were shifted to broiler houses through environmental control vehicles $23 \mathrm{C}^{0}$ and $65 \%$ humidity to access the outcomes from the hairline crack eggs chicks in term of FCR, feed intake and chick's mortality 


\section{Performance of chick}

The Feed Concervation Ratio (FCR) was calculated by measuring the amount of feed consumed by birds divided to the chicks weight gain. Calculating the chicks mortality percentage was possible by counting the mortality of chicks for complete flock divided to total number of chicks and multiply by 100 .

FCR $(\mathrm{g} / \mathrm{g})=$ feed intake $(\mathrm{g}) /$ weight gain $(\mathrm{g})$

Mortality $(\%)=$ Number of chicks died during complete flock/ Total number of chicks in flock $\times 100$

\section{Statistical analyses}

All data were analyzed by using Statistical Analysis System package software (SAS version 9.2, SAS Institute Inc., Cary, NC, USA). All means were compared using t-test and results were presented as mean \pm SEM (standard error of the mean). Results were considered significant if $\mathrm{P}<0.05$.

\section{RESULTS AND DISCUSSION}

The eggs shell constitutes approximately $10 \%$ of the whole egg. The calcium participates $95-97 \%$ of eggs hellweight. The percentage of eggshell decreases with the increase of flock age. The percentage of eggshell was 10.65, 10.29 and $9.81 \%$ with 25, 47 and 61 weeks of age respectively. Eggshell percentages at the ages of 25, 47 and 61 weeks were 10.65, 10.29 and $9.81 \%$, respectively (Salahi et al., 2011). That's the reason the percentage of crack eggs increase with respect to flock age (Table 1). The flock SP117-1 and SP117-2 have the maximum percentage of hairline crack eggs followed by SSF1, SSF5 and SSF6. The flocks SSF2 and AP27 have a minimum percentage of hairline crack eggs due to young age. The eggshell is essential in providing the shape of an egg to assure the safe packaging. Samiullah et al. (2014) found that egg weight, shell weight and shell thickness decreases with flock age. The eggs internal quality albumin heights decreased with flock age. The amount of cuticle also varied with flock age. Due to change in eggshell quality with chicken age, the defects in eggshell like breakage increases and risk of microbial contamination to eggs increases. This microbial contamination becomes a source of embryonic mortality at any stage of incubation (Jabbar and Ditta, 2017a), becomes a source of low hatchability and high candling (Table 2). Significant difference $(\mathrm{P}<0.05)$ was found for hatchability, candling, blasting/putrification and dead in the shell for normal and hairline crack eggs. The highest hatchability $(49.07 \pm 0.51)$ and lowest candling $(9.98 \pm 0.064)$ for hairline crack eggs were found for AP27 due to young age and good quality eggshell. The lowest hatchability was found for SP117 which was the oldest flock having thin egg shells (Table 2).

The breakage of eggshell and shell membrane exposes the growing embryo to contamination. The contamination may cause embryonic mortality depending on the severity of infection at any stage of incubation (Barnett et al., 2004). The crack eggs are a good source of microbial contamination, result in putrification and blasting during transfer of eggs from setter machine to hatchers. The high blasting/purification and dead in the shell are mainly due to penetration of microbes through eggshell from eggs surface. The egg shell and shell membrane is a barrier to avoid such kind of contamination. The breakage of these barriers provides easy access for microbes to infect the embryo cause its death and enhances dead in shell. The blasting/putrification and dead in the shell were significantly $(\mathrm{P}<0.05)$ higher for hairline crack eggs as compared with normal eggs of same flocks. The highest blasting and dead in the shell of hairline crack eggs were indicated in table 2. The lowest blasting was found for AP27 due to young age and good quality eggshell (Table 2).

The percentage of third week embryonic mortality was higher for a hairline crack eggs up to $7.9 \%$ as compared to normal eggs $(6.8 \%)$. The maximum quantity of contaminated eggs was found during simple hatch debris analysis for a hairline crack eggs $(7.8 \%)$ as compared to normal eggs (2.3\%). The effect of shell quality at second week of embryonic period on mortality and crack shell were the same for both kinds of eggs. The infertile eggs were also higher in hairline crack eggs $(1.0 \%)$ as compared to normal eggs $(0.6 \%)$. The term external pipes are used for such kind of chicks which can break both shell membrane and eggshell during the hatching process but unable to come out from eggs due to any reason. The external pips may be due to low humidity in hatchers near pipping, weak chicks due to the young age of breeders and infection which causes omphalitis. Amare et al. (2013) found that Escherichia coli (51.17\%) was most prominent followed by Staphylococcus (23.53), Proteus microbes (22.94) and other bacteria like streptococcus and Bacillus species were most prominent for development of yolk sac infection. The infection may start at any stage of incubation depending upon severity form eggs surface to the growing embryo. Such kinds of infections increase if the barriers for growing embryo are broken like hairline crack eggs.

Chick yield and water loss are related to each other. The chick yield is a percentage of chick conversion from the egg. We found better chick yield and water loss for normal unbroken eggs as compared to a hairline crack eggs (Table 4). The water loss and chick yield are related to each other, water loss less than standard level (11-12\%) becomes a source for ascites and early embryonic mortality during the brooding phase. The water loss more than standard causes 
low chick yield result in dehydration (Jabbar and Ditta, 2017b). The water loss, chick yield and culling chicks were significantly $(\mathrm{P}<0.05)$ better for normal eggs as compared to hairline crack eggs. The young flocks AP27 R1, AP27R2, SSF2R1, SSF2R2 and SSF8 were better even for hairline crack eggs compared to old flocks due to the better quality eggshell.

Simple hatch debris analysis was performed to access the percentage of infertile, early embryonic mortality, mid, late embryonic mortality, external pips, contaminated eggs, poor shell quality eggs and crack shell eggs for flock SSF5 normal eggs and hairline crack eggs (Jabbar and Ditta, 2017a-c).

The chicks from normal $(n=30000)$ and hairline crack eggs $(n=30000)$ were shifted to broiler houses through environmental control vehicles $23^{\circ} \mathrm{C}$ and $65 \%$ humidity to access the outcomes from the hairline crack eggs chicks in term of FCR, feed intake and chick's mortality. The environmental conditions were kept the same for both kinds of chicks from brooding to raring to minimize any kind of stress (Table 5). The chicks from normal eggs were significantly $(\mathrm{P}<0.05)$ better feed intake, weight gain, FCR and mortality (Table 6).

Table 2. Hatchability and candling of hairline crack and normal eggs

\begin{tabular}{|c|c|c|c|c|}
\hline \multirow{2}{*}{ Flocks } & \multicolumn{2}{|c|}{ Hatchability } & \multicolumn{2}{|c|}{ Candling/Infertile } \\
\hline & Normal & Hairline & Hairline & Normal \\
\hline Salman Poultry Flock 117-2 & $77.69 \pm 0.1^{\mathrm{a}}$ & $41.41 \pm 0.02^{\mathrm{b}}$ & $39.19 \pm 0.05^{\mathrm{a}}$ & $13.41 \pm 0.81^{\mathrm{b}}$ \\
\hline Salman Poultry Flock 117-1-AI-B & $86.42 \pm 0.2^{\mathrm{a}}$ & $43.03 \pm 0.07^{\mathrm{b}}$ & $36.36 \pm 0.014^{\mathrm{a}}$ & $4.16 \pm 0.19^{b}$ \\
\hline Salman Poultry Flock 117-1-AI-C & $86.80 \pm 0.1^{\mathrm{a}}$ & $40.00 \pm 0.31^{\mathrm{b}}$ & $39.39 \pm 0.014^{\mathrm{a}}$ & $4.01 \pm 0.17^{\mathrm{b}}$ \\
\hline Salman Poultry Flock 117-1-AI-D & $86.57 \pm 0.11^{\mathrm{a}}$ & $42.42 \pm 0.14^{\mathrm{b}}$ & $36.36 \pm 0.064^{\mathrm{a}}$ & $3.98 \pm 0.14^{\mathrm{b}}$ \\
\hline Salman Poultry Flock 117-1-AI-E & $86.63 \pm 0.2^{\mathrm{a}}$ & $39.39 \pm 0.57^{\mathrm{b}}$ & $38.79 \pm 0.016^{\mathrm{a}}$ & $4.02 \pm 0.15^{\mathrm{b}}$ \\
\hline SP117-1-AI-F & $86.95 \pm 0.2^{\mathrm{a}}$ & $45.45 \pm 0.14^{\mathrm{b}}$ & $33.33 \pm 0.025^{\mathrm{a}}$ & $3.90 \pm 0.17^{\mathrm{b}}$ \\
\hline Salman Sadiq Flock -5 & $72.59 \pm 0.1^{\mathrm{a}}$ & $42.42 \pm 0.15^{\mathrm{b}}$ & $34.55 \pm 0.047^{\mathrm{a}}$ & $13.46 \pm 0.61^{\mathrm{b}}$ \\
\hline Salman Sadiq Flock F-6 & $77.54 \pm 0.3^{\mathrm{a}}$ & $44.24 \pm 0.34^{\mathrm{b}}$ & $33.3 \pm 0.019^{\mathrm{a}}$ & $9.86 \pm 0.31^{\mathrm{b}}$ \\
\hline Salman Sadiq Flock 1-R1-AI-C & $82.00 \pm 0.09^{\mathrm{a}}$ & $40.91 \pm 0.92^{\mathrm{b}}$ & $36.67 \pm 0.071^{\mathrm{a}}$ & $6.21 \pm 0.61^{\mathrm{b}}$ \\
\hline SSF1-R2-AI-A & $80.71 \pm 0.31^{\mathrm{a}}$ & $40.40 \pm 0.84^{\mathrm{b}}$ & $35.96 \pm 0.064^{\mathrm{a}}$ & $7.02 \pm 0.43^{\mathrm{b}}$ \\
\hline Salman Sadiq Flock 1-R2-AI-B & $82.30 \pm 0.04^{\mathrm{a}}$ & $41.52 \pm 0.47^{\mathrm{b}}$ & $35.15 \pm 0.017^{\mathrm{a}}$ & $5.07 \pm 0.13^{\mathrm{b}}$ \\
\hline Salman Sadiq Flock 1-R3-AI-D & $81.07 \pm 0.02^{\mathrm{a}}$ & $43.33 \pm 0.24^{b}$ & $34.85 \pm 0.027^{\mathrm{a}}$ & $6.94 \pm 0.98^{b}$ \\
\hline Arslan Poultry 27-R1 & $93.61 \pm 0.07^{\mathrm{a}}$ & $49.07 \pm 0.51^{b}$ & $9.98 \pm 0.064^{\mathrm{a}}$ & $4.18 \pm 0.61^{\mathrm{b}}$ \\
\hline
\end{tabular}

${ }^{\mathrm{a}-\mathrm{b}}$ denote difference for hatchability and candling of normal and hairline crack eggs within rows $(\mathrm{P}<0.05)$

Table 3. Putrification of dead in shell of hairline crack and normal eggs

\begin{tabular}{|c|c|c|c|c|}
\hline \multirow{2}{*}{ Flocks } & \multicolumn{2}{|c|}{ Blasting/Putrification } & \multicolumn{2}{|c|}{ Dead in Shell } \\
\hline & Hairline & Normal & Hairline & Normal \\
\hline Salman Poultry Flock 117-2 & $12.1 \pm 0.64^{\mathrm{a}}$ & $5.14 \pm 0.48^{b}$ & $19.39 \pm 0.61^{\mathrm{a}}$ & $8.90 \pm 0.25^{b}$ \\
\hline Salman Poultry Flock 117-1-AI-B & $15.15 \pm 0.31^{\mathrm{a}}$ & $5 \pm 0.71^{\mathrm{b}}$ & $20.61 \pm 0.24^{\mathrm{a}}$ & $9.42 \pm 0.34^{\mathrm{b}}$ \\
\hline Salman Poultry Flock 117-1-AI-C & $10.30 \pm 0.61^{\mathrm{a}}$ & $1.5 \pm 0.61^{\mathrm{b}}$ & $20.61 \pm 0.61^{\mathrm{a}}$ & $9.18 \pm 0.24^{b}$ \\
\hline Salman Poultry Flock 117-1-AI-D & $9.09 \pm 0.95^{\mathrm{a}}$ & $1.5 \pm 0.21^{\mathrm{b}}$ & $21.21 \pm 0.14^{\mathrm{a}}$ & $9.45 \pm 0.21^{\mathrm{b}}$ \\
\hline Salman Poultry Flock $117-1-$ AI-E & $7.57 \pm 0.97^{\mathrm{a}}$ & $1.5 \pm 0.64^{\mathrm{b}}$ & $21.82 \pm 0.31^{\mathrm{a}}$ & $9.35 \pm 0.36^{\mathrm{b}}$ \\
\hline Salman Poultry Flock 117-1-AI-F & $7.27 \pm 0.68^{\mathrm{a}}$ & $1.5 \pm 0.34^{\mathrm{b}}$ & $21.21 \pm 0.15^{\mathrm{a}}$ & $9.15 \pm 0.36^{\mathrm{b}}$ \\
\hline Salman Sadiq Flock -5 & $10.3 \pm 0.16^{\mathrm{a}}$ & $1.5 \pm 0.81^{\mathrm{b}}$ & $23.03 \pm 0.17^{\mathrm{a}}$ & $12.95 \pm 0.24^{\mathrm{b}}$ \\
\hline Salman Sadiq Flock -6 & $13.63 \pm 0.46^{\mathrm{a}}$ & $1.5 \pm 0.15^{\mathrm{b}}$ & $22.42 \pm 0.34^{\mathrm{a}}$ & $12.60 \pm 0.64^{\mathrm{b}}$ \\
\hline Salman Sadiq Flock 1-Ross1-AI-C & $10.3 \pm 0.57^{\mathrm{a}}$ & $1.5 \pm 0.93^{\mathrm{b}}$ & $22.42 \pm 0.31^{\mathrm{a}}$ & $11.79 \pm 0.37^{\mathrm{b}}$ \\
\hline Salman Sadiq Flock 1-Ross2-AI-A & $11.71 \pm 0.94^{\mathrm{a}}$ & $1.5 \pm 0.65^{\mathrm{b}}$ & $23.01 \pm 0.27^{\mathrm{a}}$ & $12.27 \pm 0.27^{b}$ \\
\hline Salman Sadiq Flock 1-Ross2-AI-B & $9.09 \pm 0.39^{\mathrm{a}}$ & $1.5 \pm 0.87^{\mathrm{b}}$ & $23.01 \pm 0.61^{\mathrm{a}}$ & $12.63 \pm 0.61^{\mathrm{b}}$ \\
\hline Salman Sadiq Flock 1-R3-AI-D & $10.57 \pm 0.68^{\mathrm{a}}$ & $1 \pm 0.51^{\mathrm{b}}$ & $21.82 \pm 0.34^{\mathrm{a}}$ & $11.99 \pm 0.91^{\mathrm{b}}$ \\
\hline Arslan Poultry 27-R1 & $5.12 \pm 0.97^{\mathrm{a}}$ & $0.97 \pm 0.81^{\mathrm{b}}$ & $12.75 \pm 0.31^{\mathrm{a}}$ & $2.09 \pm 0.64^{\mathrm{b}}$ \\
\hline
\end{tabular}

Table 4. Effect of hairline crack eggs on chick yield, water loss and culling chicks

\begin{tabular}{|c|c|c|c|c|c|c|}
\hline \multirow{2}{*}{ Flocks } & \multicolumn{2}{|c|}{ Chick Yield (\%) } & \multicolumn{2}{|c|}{ Water loss $(\%)$} & \multicolumn{2}{|c|}{ Culling $(\%)$} \\
\hline & Normal Eggs & Hairline crack & Normal Eggs & Hairline crack & Normal Eggs & Hairline crack \\
\hline Salman Poultry Flock 117-2 & $69 \pm 0.1^{\mathrm{a}}$ & $66 \pm 0.21^{\mathrm{b}}$ & $12.1 \pm 065^{\mathrm{a}}$ & $14.3 \pm 0.24^{\mathrm{b}}$ & $1.21 \pm 0.34^{\mathrm{a}}$ & $2.1 \pm 0.34^{\mathrm{b}}$ \\
\hline Salman Poultry Flock 117-1-AI-B & $69 \pm 0.02^{\mathrm{a}}$ & $67 \pm 0.014^{\mathrm{b}}$ & $12.4 \pm 0.31^{\mathrm{a}}$ & $14.65 \pm 0.5^{\mathrm{b}}$ & $1.2 \pm 0.42^{\mathrm{a}}$ & $2.01 \pm 0.61^{\mathrm{b}}$ \\
\hline Salman Poultry Flock 117-1-AI-C & $68 \pm 0.01^{\mathrm{a}}$ & $66 \pm 0.051^{\mathrm{b}}$ & $12.3 \pm 0.32^{\mathrm{a}}$ & $13.98 \pm 0.34^{\mathrm{b}}$ & $1.02 \pm 0.31^{\mathrm{a}}$ & $2.3 \pm 0.12^{\mathrm{b}}$ \\
\hline Salman Poultry Flock 117-1-AI-D & $69 \pm 0.21^{\mathrm{a}}$ & $67 \pm 0.01^{\mathrm{b}}$ & $11.87 \pm 0.6^{\mathrm{a}}$ & $14.9 \pm 0.37^{\mathrm{b}}$ & $1.1 \pm 0.32^{\mathrm{a}}$ & $2.14 \pm 0.24^{\mathrm{b}}$ \\
\hline Salman Poultry Flock 117-1-AI-E & $69 \pm 0.21^{\mathrm{a}}$ & $65 \pm 0.02^{b}$ & $11.91 \pm 0.6^{\mathrm{a}}$ & $14.57 \pm 0.7^{\mathrm{b}}$ & $1.3 \pm 0.91^{\mathrm{a}}$ & $2.15 \pm 0.51^{\mathrm{b}}$ \\
\hline Salman Poultry Flock 117-1-AI-F & $68 \pm 0.03^{\mathrm{a}}$ & $66 \pm 0.01^{\mathrm{b}}$ & $11.54 \pm 0.6^{\mathrm{a}}$ & $14.87 \pm 0.24^{\mathrm{b}}$ & $1.3 \pm 0.34^{\mathrm{a}}$ & $2.31 \pm 0.64^{\mathrm{b}}$ \\
\hline Salman Sadiq Flock -R1-AI-C & $69 \pm 0.04^{\mathrm{a}}$ & $67 \pm 0.031^{\mathrm{b}}$ & $12.6 \pm 0.6^{\mathrm{a}}$ & $14.56 \pm 0.94^{\mathrm{b}}$ & $1.2 \pm 0.51^{\mathrm{a}}$ & $2.14 \pm 0.46^{\mathrm{b}}$ \\
\hline Salman Sadiq Flock 1-R2-AI-A & $69 \pm 0.03^{\mathrm{a}}$ & $65 \pm 0.014^{\mathrm{b}}$ & $12.14 \pm 0.7^{\mathrm{a}}$ & $15.34 \pm 0.1^{\mathrm{b}}$ & $1.2 \pm 0.51^{\mathrm{a}}$ & $2.64 \pm 0.64^{b}$ \\
\hline Salman Sadiq Flock 1-R2-AI-B & $69 \pm 0.01^{\mathrm{a}}$ & $66 \pm 0.015^{\mathrm{b}}$ & $12.3 \pm 0.7^{\mathrm{a}}$ & $16.2 \pm 0.9^{\mathrm{b}}$ & $1.2 \pm 0.44^{\mathrm{a}}$ & $3.14 \pm 0.67^{b}$ \\
\hline Salman Sadiq Flock 1-R3-AI-D & $68 \pm 0.02^{\mathrm{a}}$ & $65 \pm 0.01^{\mathrm{b}}$ & $11.89 \pm 0.6^{\mathrm{a}}$ & $16.65 \pm 0.93^{\mathrm{b}}$ & $1.2 \pm 0.94^{\mathrm{a}}$ & $3.1 \pm 0.51^{\mathrm{b}}$ \\
\hline
\end{tabular}


Salman Sadiq Flock -5

Salman Sadiq Flock -6

Arslan Poultry flock 27-R2

Arslan Poultry 27 flock-R1

Salman Sadiq Flock 2-R1

Salman Sadiq Flock 2-R2

Salman Sadiq Flock F8

$\begin{array}{llllll}69 \pm 0.02^{\mathrm{a}} & 65 \pm 0.01^{\mathrm{b}} & 11.68 \pm 0.7^{\mathrm{a}} & 15.98 \pm 0.6^{\mathrm{b}} & 1.3 \pm 0.71^{\mathrm{a}} & 3.1 \pm 0.58^{\mathrm{b}} \\ 69 \pm 0.02^{\mathrm{a}} & 65 \pm 0.02^{\mathrm{b}} & 12.67 \pm 0.3^{\mathrm{a}} & 16.74 \pm 0.6^{\mathrm{b}} & 1.31 \pm 0.64^{\mathrm{a}} & 3.12 \pm 0.64^{\mathrm{b}} \\ 69 \pm 0.03^{\mathrm{a}} & 67 \pm 0.03^{\mathrm{b}} & 11.39 \pm 0.6^{\mathrm{a}} & 12.69 \pm 0.9^{\mathrm{b}} & 0.98 \pm 0.81^{\mathrm{a}} & 1.89 \pm 0.57^{\mathrm{b}} \\ 68 \pm 0.20^{\mathrm{a}} & 66 \pm 0.01^{\mathrm{b}} & 11.24 \pm 0.2^{\mathrm{a}} & 12.51 \pm 0.5^{\mathrm{b}} & 0.97 \pm 0.36^{\mathrm{a}} & 1.84 \pm 0.96^{\mathrm{b}} \\ 69 \pm 0.01^{\mathrm{a}} & 67 \pm 0.04^{\mathrm{b}} & 11.68 \pm 0.2^{\mathrm{a}} & 13.14 \pm 0.6^{\mathrm{b}} & 0.98 \pm 0.89^{\mathrm{a}} & 1.89 \pm 0.58^{\mathrm{b}} \\ 69 \pm 0.04^{\mathrm{a}} & 66 \pm 0.03^{\mathrm{b}} & 12.67 \pm 0.5^{\mathrm{a}} & 12.69 \pm 0.5^{\mathrm{b}} & 0.97 \pm 0.48^{\mathrm{a}} & 1.84 \pm 0.74^{\mathrm{b}} \\ 68 \pm 0.21^{\mathrm{a}} & 67 \pm 0.20^{\mathrm{b}} & 11.39 \pm 0.5^{\mathrm{a}} & 13.51 \pm 0.35^{\mathrm{b}} & 0.98 \pm 0.54^{\mathrm{a}} & 1.89 \pm 0.54^{\mathrm{b}}\end{array}$

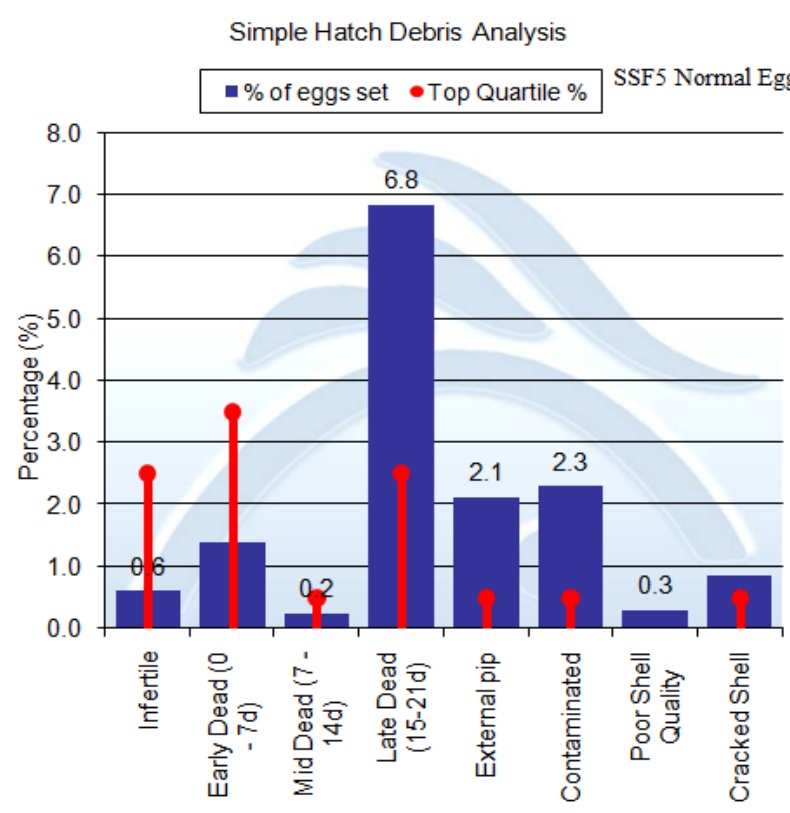

Figure 1. Dead in shell analysis of normal eggs at Chakri hatchery Rawalpindi, Pakistan

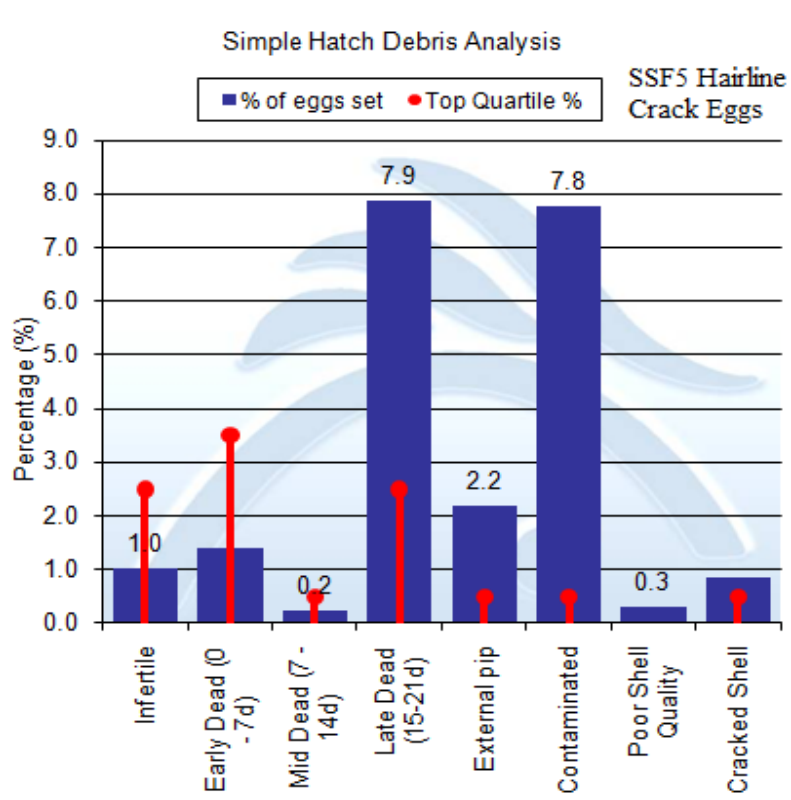

Figure 2. Dead in shell analysis of hairline crack eggs at Chakri hatchery Rawalpindi, Pakistan

Table 5. The temperature, humidity and ventilation of poultry house

\begin{tabular}{lccccc}
\hline Parameters & First week & Second week & Third week & Fourth week & Fifth week \\
\hline Temperature $\left({ }^{0} \mathrm{~F}\right)$ & $95-86$ & $86-83$ & $83-77$ & $77-75$ & 75 \\
Humidity $(\%)$ & 65 & 65 & 65 & 65 & 65 \\
Ventilation $\left(\mathrm{m}^{3} /\right.$ hour/ bird $)$ & 0.07 & 0.25 & 0.4 & 0.59 & 0.87 \\
\hline
\end{tabular}

Table 6. The effect of hairline crack eggs on chick's mortality and performance traits

\begin{tabular}{lcc}
\hline Parameters & Normal eggs chicks & Hairline crack egg chicks \\
\hline Mortality $(\%)$ & $1.86 \pm 0.06^{\mathrm{a}}$ & $3.17 \pm 0.31^{\mathrm{b}}$ \\
Weight gain $(\mathrm{g})$ & $2200 \pm 0.14^{\mathrm{a}}$ & $1855 \pm 0.071^{\mathrm{b}}$ \\
Feed intake $(\mathrm{g})$ & $3255 \pm 0.21^{\mathrm{a}}$ & $3310 \pm 0.091^{\mathrm{b}}$ \\
Feed conversion ratio (\%) & $1.82 \pm 0.038^{\mathrm{a}}$ & $1.57 \pm 0.048^{\mathrm{b}}$ \\
\hline $\mathrm{a}-\mathrm{b}$ denote significant difference for mortality, weight gain, feed intake and FCR of chicks from normal and hairline crack eggs $(\mathrm{P}<0.05)$
\end{tabular}

\section{CONCLUSION}

The eggshell and shell membrane are barriers for growing embryo provide safe packaging and avoid contamination. The damages to these barriers negatively affected the hatchery parameters and quality of chicks in present study. The chicks of hairline crack eggs become a source of economic loss in term of FCR and feed intake.

\section{DECLARATIONS}

\section{Author's contribution}

Dr. A. Jabbar and Dr. Abdul Hameed were responsible for designing the experiment and gathering the data along the result analysis under the supervision of Dr. A. Riaz and Dr.Yasir Allah Ditta. Finally Dr. Adnan Yousaf wrote the article and checked the statistical application. 


\section{Acknowledgments}

The authors are thankful to Director of Salman Poultry (Pvt) limited Mr. Salman Sadiq for their full support and encouragement during the whole period of research work. Authors are also great full to hatchery supervisor Mr. Muhammad Ashfaq and Plant operator Mr. Muhammad Akhtar, Engr. Jawad Kiwan Qazi and Engr. Mirza Shahbaz Baig for their cooperation.

\section{Competing interests}

The authors declare that they have no conflict of interest with respect to the research, authorship and/or publication of this research.

\section{REFERENCES}

Salahi A, Moosanezhad Khabisi M and Mousavi SN (2011). Effects of the length (size) of eggshell cracks on hatchability and chick qualityof broiler breeder flocks. European symposium on the quality of poultry meat, p.52.

Amare A, Amin AM, ShiferawA, Nazir S and Negussie H (2013). Yolk Sac Infection (Omphalitis) in Kombolcha Poultry Farm, Ethiopia American-Eurasian. Journal of Scientific Research 8 (1): 10-14, 2013. Doi: 10.5829/idosi.aejsr.2013.8.1.65108

Barnett DM, Kumpula BL, Petryk R, Robinson L, Renema RA and Robinson FE (2004). Hatchability and Early Chick Growth Potential of Broiler Breeder Eggs with Hairline Cracks. Poultry Science Association, 65-70. Doi: 10.1093/japr/13.1.65

Jabbar A and Ditta YA (2017a). Effect of Floor Eggs on Hatchability, Candling, Water Loss, Chick Yield, Chick Weight and Dead in Shell. Journal of World`s Poultry Research, 7(4): 154-158.

Jabbar A and Ditta YA (2017b). Incubation Duration of Broiler Breeder Egg and Post Hatch Performance. Worlds Veterinary Journal, 7(3): 83-88. Doi: http://dx.doi.org/10.5455/wvj.20170897

Jabbar A and Ditta YA (2017c). Effect of Broiler Breeders Age on Hatchability, Candling, Water Loss, Chick Yield and Dead in Shell. World's Veterinary Journal, 7(2): 40-46.

Khabisi MM, Salahi A and Mousavi SN (2011). The influence of eggshell crack types on hatchability and chick quality. European Symposium on poultry nutrition Poster presentation 3-4 November. Available at: http://journals.tubitak.gov.tr/veterinary/issues/vet-12-36-3/vet-36-3-11-1103-20.pdf

King'ori AM (2012). Egg quality defects: Types, causes and occurrence: a review. Journal of Animal Production Advances; 2:350-7.

NoivaRute M, MenezesAntónio C and Peleteiro Maria C (2014). Influence of temperature and humidity manipulation on chicken embryonic development. BMC Veterinary Research, 10:234. Doi: 10.1371/journal.pone.0103040

Samiullah Roberts JR and Chousalkar KK (2014). Effect of production system and flock ageon egg quality and total bacterial loadin commercial laying hens. Journal of Applied Poultry Research, 23:59-70. Doi:http://dx.doi.org/ 10.3382/japr.2013-00805

Van den Brand H, Sosef MP, Lourens A, and van Harn J (2016).Effects of floor eggs on hatchability and later life performance in broiler Chickens. Poultry Science, 95:1025-1032. Doi: http://dx.doi.org/10.3382/ps/pew008

Wellman Labadie O, Picman J and Hincke MT (2008). Antimicrobial activity of the Anseriform outer eggshell and cuticle. Comparative Biochemistry Physiology B: Biochemistry and Molecular Biology, 149: 640-649. Doi: https://doi.org/10.1016/j.cbpb.2008.01.001

Wei LU, Chengyu ZHANG, HuiLuo, Weimin DING and Lin WANG (2015). Micro-Cracks Detection of Eggshells Based on a Magnetostrictive Transducer. Sensors \& Transducers, 186: 49-54.

Xie C and He Y (2016). External characteristic determination of eggs and cracked eggs identification using spectral signature. Scientific Reports, 6:21130. Doi: 10.1038/srep21130

Yousaf A, Jabbar A and Ditta YA (2017). Effect of pre-warming on broiler breeder eggs hatchability and post-hatch performance. Journal of Animal Health and Production, 5(1): 1-4. Doi: http://dx.doi.org/10.14737/journal.jahp/2017/5.1.1.4 